Primljen / Received: 11.2.2013. Ispravljen / Corrected: 12.5.2013. Prihvaćen / Accepted: 28.6.2013. Dostupno online / Available online: 25.7.2013.

\section{Expert project analyses in the process of road maintenance management}

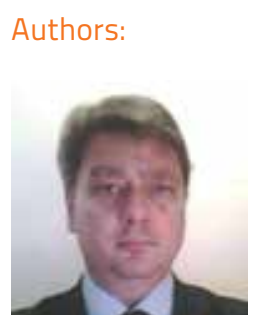

Asst. Prof. Nebojša Radović, PhD. CE University of Novi Sad

Faculty of Technical Sciences

Department of Civil Engineering and Geodesy radovicn@drenik.net

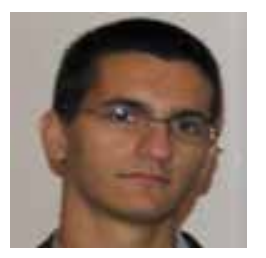

Miloš Šešlija, MSc. CE

University of Novi Sad

Faculty of Technical Sciences

Department of Civil Engineering and Geodesy sele@uns.ac.rs

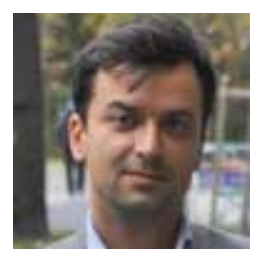

Igor Peško, MSc. CE

University of Novi Sad

Faculty of Technical Sciences

Department of Civil Engineering and Geodesy igor.pesko@gmail.com

\author{
Nebojša Radović, Miloš Šešlija, Igor Peško
}

\section{Expert project analyses in the process of road maintenance management}

An updated information system, and an appropriate decision making model, must be put in place for an efficient road maintenance management. A methodological procedure for expert project-level analyses of road maintenance and improvement activities, based on the Road Data Base (RDB) and the HDM-4 model, is presented in the paper. The procedure was successfully applied and accepted in 2012, in the scope of application for funding of road network maintenance and improvement by international financing institutions (World, Bank, EIB and EBRD).

Key words:

road management, road maintenance, HDM-4 model, project level analyses, economic evaluation

Stručni rad

Nebojša Radović, Miloš Šešlija, Igor Peško

Ekspertne projektne analize u procesu gospodarenja održavanjem cesta

Za potrebe učinkovitog gospodarenja održavanjem cestovne mreže neophodno je raspolagati s ažurnom informacijskom osnovom i odgovarajućim modelom za odlučivanje. U radu se daje prikaz metodološkog postupka za ekspertne projektne analize za radove na održavanju i poboljšanju cesta uz korišćenje Baze Cestovnih Podataka (BCP) i primjenu HDM-4 modela. Postupak je uspješno primjenjen i prihvaćen u apliciranju zahtjeva za financiranje radova na održavanju i poboljšanju cestovne mreže od strane međunarodnih financijskih institucija (Svjetska Banka, EIB i EBRD) tijekom 2012-e godine.

Ključne riječi:

gospodarenje cestama, održavanje cesta, HDM-4 model, projektne analize, ekonomska ocjena

Fachbericht

Nebojša Radović, Miloš Šešlija, Igor Peško

Experten-Projektanalysen im Verwaltungsprozess der Straßeninstandhaltung

Um eine nachhaltige Verwaltung der Instandhaltung des Straßennetzes zu erreichen, sind neuste Informationsunterlagen und entsprechende Entscheidungsmodelle notwendig. In der vorliegenden Arbeit ist ein methodologisches Verfahren für Experten-Projektanalysen in Bezug auf Arbeiten der Instandhaltung und Erneuerung von Straßen dargestellt, das auf dem Einsatz einer Straßendatenbank (BCP) und der Anwendung von HDM-4 Modellen beruht. Im Laufe des Jahres 2012 ist das Verfahren erfolgreich in Förderanträgen für Projekte der Instandhaltung und Erneuerung von Straßennetzen angewandt worden und von internationalen Finanzinstituten (Weltbank, EIB und EBRD) angenommen worden.

Straßenverwaltung, Straßeninstandhaltung, HDM-4 Modell, Projekt-Analysen, wirtschaftliche Bewertung 


\section{Introduction}

Road infrastructure is one of the most valuable assets of a society and a good indicator of development of national economy. Over the past two decades, worldwide investments in the maintenance, reconstruction and modernization of roads have been significantly higher than the investments made in the construction of new roads. Road maintenance management is the process of making very important investment decisions, and it includes resolution of a number of technical and economic issues, as well as gathering objective technical and economic information for the final decision making. The planning of road network maintenance is one of fundamental tasks of every road network operator.

A properly updated road information system, as well as an adequate decision model, must be established and put in operation so as to enable an effective management of road maintenance activities. The HDM-4 model (Highway Development and Management Model) for the analysis of investments in the development and management of roads is a complex software tool for the technical and economic evaluation of road projects, and for analyzing investments in the existing road network. The model is widely accepted by the International Financial Institutions (IFIs). The HDM-4 model can be used to: conduct strategic analyses at the level of the road network (or part of the road network), program road maintenance and improvement activities on the road network, and make analyses at the project level. The strategic and programme analyses of the road network are carried out on the basis of adequate and updated road network information base (RDB - Road Data Base), while the project-level analysis requires preparation of appropriate design and technical documentation (General, Preliminary or Final/Detailed Design). After the conduct of strategic and/or programme analyses of the road network, appropriate design and technical documentation must be prepared for selected priority sections, in accordance with the legal procedure.

A frequent practical problem is the lack of adequate technical project documentation that has to be prepared on the basis of the preliminary list of priority sections/links of the road network. This list is usually composed of a greater number of sections/ links of the road network, and the preparation of an appropriate technical project documentation (Final / Detailed Design) can be a time consuming process. At the same time, strategic and program analyses are based on the aggregate/grouped data (Information Quality Level - IQL-3 or IQL-4) of homogeneous sections/links of the road network and, in many cases, these analyses do not provide a sufficient level of information, as they are primarily aimed at obtaining a preliminary list of priority sections for works on the road network. Therefore, the strategic and/or programme analysis at road network level must immediately be followed by the expert (high-level) projectlevel analysis in order to confirm the technical and economic justification of selected priority sections/links based on a higher level of information (Information Quality Level - IQL-1 or IQL-2).
This requirement is typical in cases when periodic maintenance/ rehabilitation works and improvement works on the road network are financed by the International Financial Institutions (IFIs) and donor agencies. Expert (high-level) project analyses of periodic road maintenance/rehabilitation and improvement works are based on the analysis of data contained in the Road Data Base (RDB), engineering diagnosis of selected priority sections in order to identify additional works, and objective technical and economic evaluation of the proposed project, and invlove a more accurate application of the HDM-4 model.

This paper describes a methodological procedure for the expert (high-level) project analysis of the periodic road maintenance/ rehabilitation and improvement works, and presents a typical example of one section/link of the road network.

\section{Road maintenance management}

\subsection{Road maintenance}

Road is a capital investment whose condition deteriorates over time under the influence of various factors. The degree of road deterioration varies greatly depending on climatic conditions, strength of pavement structure and subgrade, volume of traffic, and axle load.

Road maintenance is the process that slows down road damage and deterioration and, in rare cases, it even returns the road service level to earlier values. In this context, road maintenance can be defined as "all actions undertaken to maintain and restore the serviceability and level of service of roads" (PIARC) [1].

Road maintenance works and activities can be divided into the following categories:

- Routine (regular) maintenance

- Preventive maintenance

- Periodic and increased maintenance

- Rehabilitation

- Reconstruction

- Emergency maintenance.

Figures 1 and 2 illustrate how road condition deteriorates over time and how road life may be extended by appropriate road maintenance actions, which result in significant savings for the society.

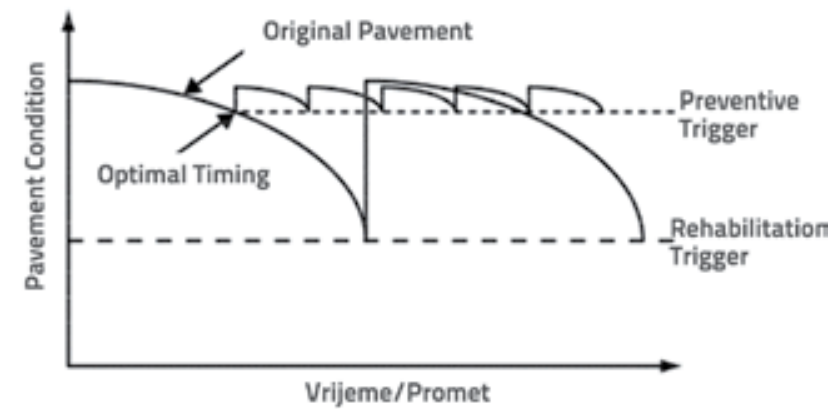

Figure 1. Preventive pavement maintenance concept (FHWA) [2] 


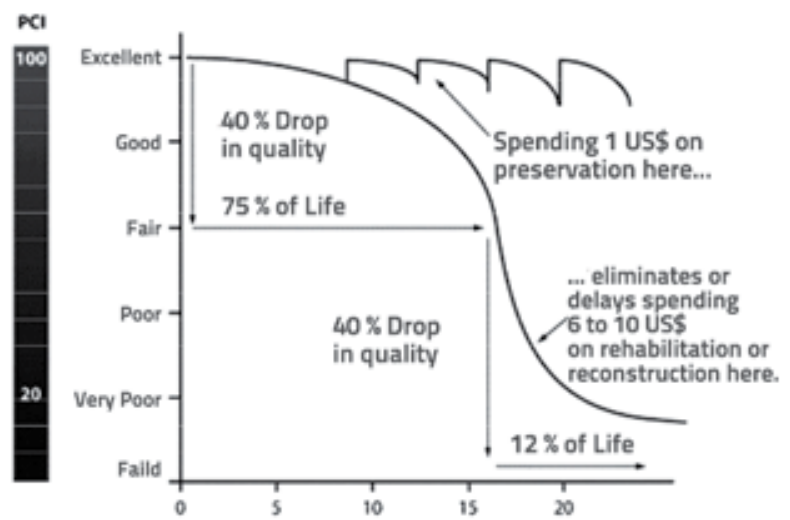

Figure 2. Pavement deterioration curve $(\mathrm{PCl}=$ Pavement Condition Index) (FHWA) [2]

In quantitative terms, when a road is not maintained adequately, each US\$ saved from not carrying out maintenance generally increases vehicle operating costs by 2-3 US\$. Thus, as illustrated in Figure 3, cutting back on road maintenance increases the costs of road transport and raises the net cost to the economy as a whole.

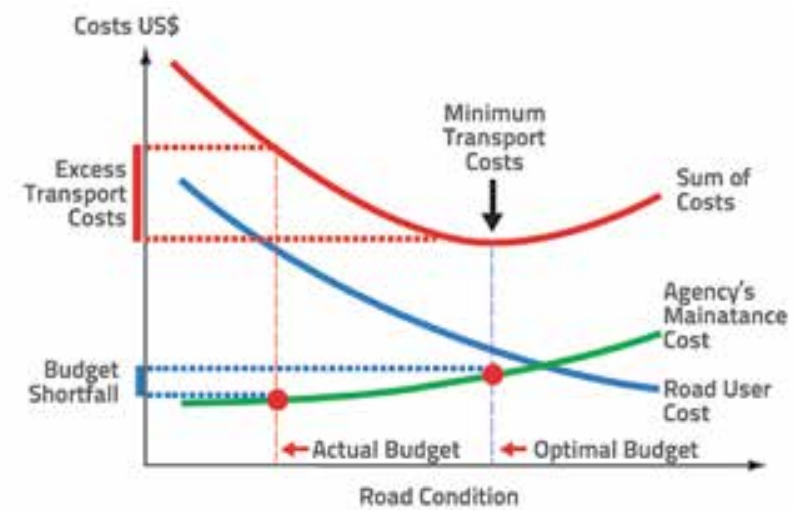

Figure 3. Relationship between road maintenance standard and transport costs [3]

\subsection{Road maintenance management}

Road maintenance management aims to identify the need for maintenance works and potential improvements of the network in order to achieve or maintain standards. In conjunction with road planning and design processes, road maintenance management attempts to optimise the overall performance of the road network over time. At a practical level, it aims to ensure that the correct activities are performed on the network at the right time, and to the desired quality.

The process comprises a series of management functions. In simple terms, maintenance management aims to get the right people, materials and equipment, to the right place on the road network, to carry out the right remedial or preventative work, at the right time.
Maintenance management is essentially a systematic means of efficient planning, programming, budgeting, scheduling, controlling, data collection, and monitoring of maintenance works.

There are four distinct and inter-related components of road maintenance which, taken together, comprise a management framework enabling a successful response to the maintenance challenge. As illustrated in Figure 4, these are:

- Planning,

- Programming,

- Preparations and

- Operations.

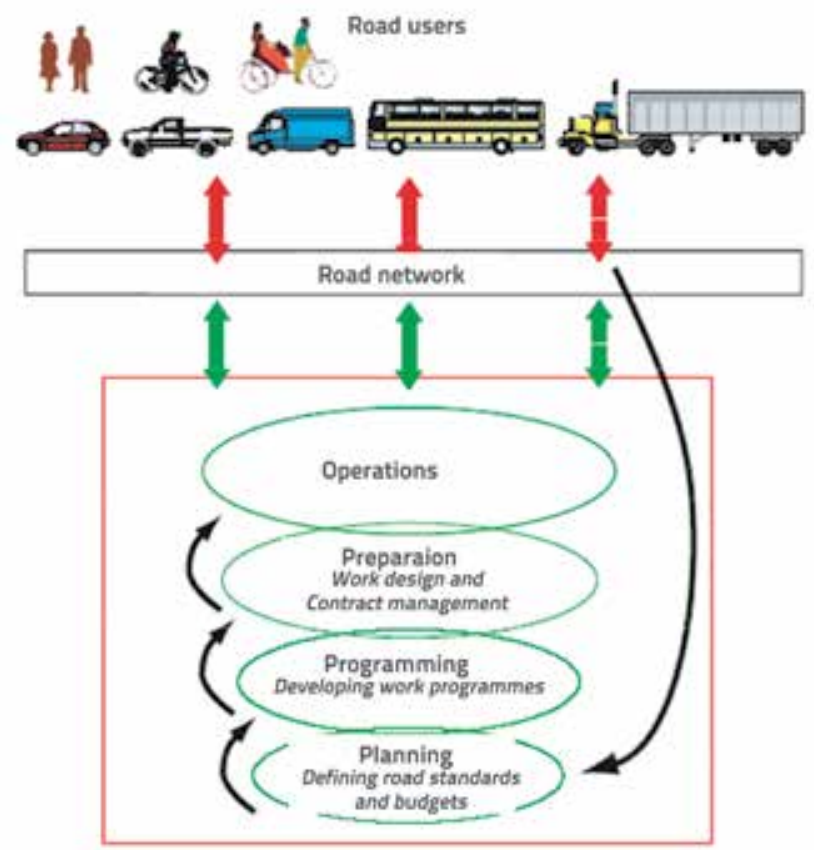

Figure 4. Road maintenance management functions [4]

\subsection{Information Quality Level - IQL}

The IQL (Information Quality Level) concept was introduced in the nineties to enable the use of different levels and quality of data for different levels of analysis.

The IQL concept allows us to structure road management information in ways that suit the needs of different levels of decision making and the variety of effort and sophistication of methods for collecting and processing data. In the IQL concept, very detailed information at a low level ('low-level data') can be condensed or aggregated into progressively fewer items at successively higher levels of IQL ('high-level data'), as shown in Figure 5 [5].

In terms of data requirements, the key difference between the strategy and programme analyses, and the project analysis, lies in the detail at which data are defined. Project level analysis data are specified in terms of measured defects (IQL2), whereas the specification for strategy and programme analyses can be more generic (IQL-3 or IQL-4). 


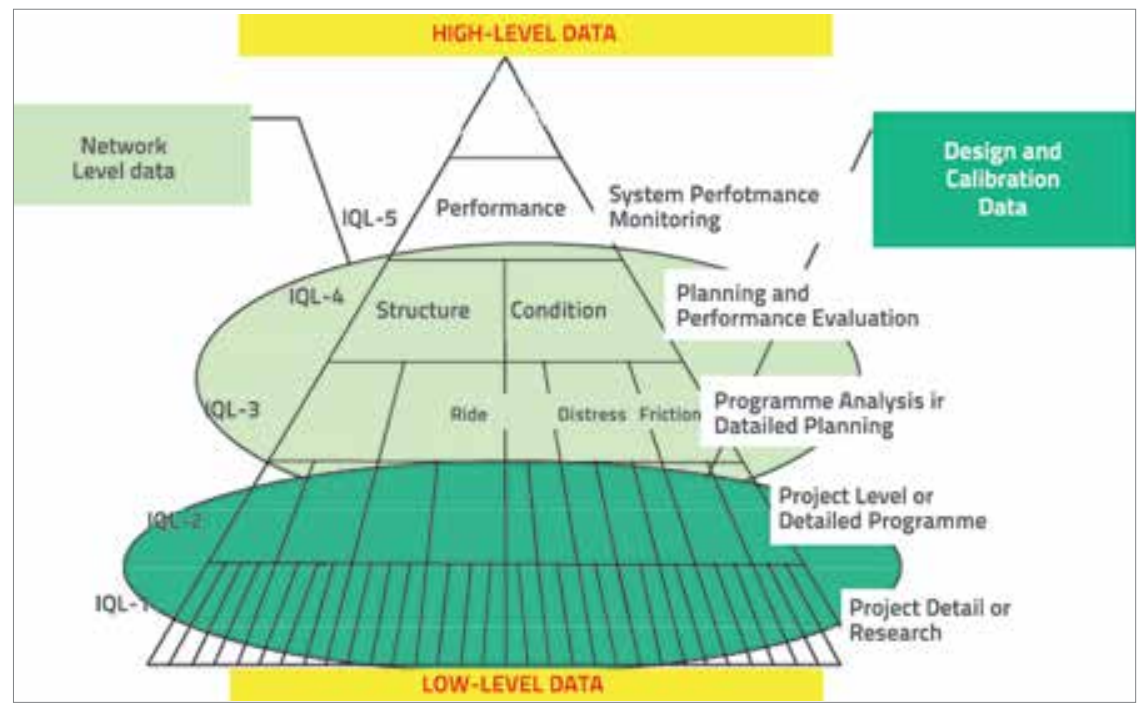

Figure 5. Information Quality Level - IQL [5] the road network is about 13 billion dollars. The second part of the network consists of municipal or local roads $(23,780 \mathrm{~km})$ which, together with the street network, are managed by local authorities [6].

\subsection{Maintenance of public roads}

According to Article 57 of the Law, maintenance of public roads implies works that ensure smooth and safe traffic and enable proper usability of roads. The public road manager shall ensure smooth and safe operation of traffic, and provide for the usability of roads. According to Article 57 of the Law, public road maintenance includes routine, periodic and emergency maintenance operations [7].
For instance, for the project level analysis, the road roughness would be specified in terms of the IRI value $(\mathrm{m} / \mathrm{km})$, while for the strategy and programme analyses the level of roughness can be specified as good, fair or poor.

\section{Road network of the Republic of Serbia}

\subsection{General data on the road network}

The road network of the Republic of Serbia measuring 40,845 $\mathrm{km}$ in total length consists of: [6]

- 5,525 km of category I state roads (main roads)

- $11,540 \mathrm{~km}$ of category II state roads (regional roads)

- 23,780 km of local roads.

The road network contains:

- $498 \mathrm{~km}$ of toll motorways

- $136 \mathrm{~km}$ of toll semi-motorways.

\subsection{Road network management}

The state road network (categories I and II), which represents $40.1 \%$ of the total road network of the Republic of Serbia, is managed by the Public Enterprise "Roads of Serbia". Almost all roads in this category have a modern paved surface but the pavement condition varies. It is estimated that the total value of
Routine maintenance on a public road inter alia includes:

- Inspection, identification and assessment of the condition of a public road and structures

- Repair of pavement structure and other road elements in places

- Cleaning pavement surface and other road elements within the right-of-way

- Finishing shoulders

- Finishing and preserving the embankment, cutting and cut-and-fill slopes

- Cleaning and finishing ditches, channels, culverts and other elements of the drainage system

- Repair of road structures

- Setting, replacement, supplementing, and repair of traffic signs and signals

- Cleaning traffic signs and signals

- Placing, replacing, supplementing, and repairing road furniture and structures, as well as road traffic and environmental protection devices

- Cleaning of road furniture and road traffic and environmental protection devices

- Mowing grass and caring for green areas along public road, within the right-of-way

- Removal of snow and ice from the pavement on a public road, at bus bays, car parks, shoulders, and open channels.

Table 1. Road network of the Republic of Serbia

\begin{tabular}{|c|c|c|c|c|c|c|}
\hline \multicolumn{4}{|c|}{ Category I state roads } & \multirow{2}{*}{$\begin{array}{c}\text { Category II state } \\
\text { roads }\end{array}$} & \multirow{2}{*}{ Local roads } & \multirow{2}{*}{ Total } \\
\hline Motorways & Semi-motorways & Other & Total & & & \\
\hline $498 \mathrm{~km}$ & $136 \mathrm{~km}$ & 4,891km & $\begin{array}{c}\text { (A) } \\
5,525 \mathrm{~km}\end{array}$ & $\begin{array}{c}\text { (B) } \\
11,540 \mathrm{~km}\end{array}$ & $\begin{array}{c}\text { (C) } \\
23,780 \mathrm{~km}\end{array}$ & $\begin{array}{c}(A+B+C) \\
40,845 \mathrm{~km}\end{array}$ \\
\hline
\end{tabular}


Periodic maintenance on public roads includes pavement structure strengthening, rehabilitation and intensified road maintenance.

Emergency maintenance of public roads includes actions that are made necessary because of natural catastrophes and extraordinary circumstances, and is conducted in order to ensure road passability and safe operation of traffic.

\section{Programme analyses of the state road network, categories I and II}

The Programme Analysis covered 709 homogeneous sections/links of the state road network (categories I and II) of the Republic of Serbia in the total length of 13,191.34 km. These roads were classified as follows: motorways and semimotorways, main roads and regional roads [8]. Homogeneous sections of each category of the road network are determined based on the following criteria:

- Road class (motorway/semi motorway, main road, regional road)

- Road type (G-city street, PG-suburban, AC-highway, GACcity highway, PAC-semi-highway)

- Pavement type (paved, unpaved)

- Changes in traffic volume (Average Annual Daily Traffic AADT, veh/day)

- Changes in pavement surface roughness (IRI, m/km)

- Length of homogeneous actions at the level of future contracts for the periodic maintenance/rehabilitation or improvement works on roads.

The Road Data Base (RDB) was the basis for defining proposal of the mid-term work programme (2012-2016) of periodic maintenance/rehabilitation and improvement works on the state road network, categories I and II. Data on the road network were collected in 2008 and 2009 in the scope of the Transport Rehabilitation Project in Serbia, which was financed by the World Bank [8].

Table 2 shows the basic average characteristics of the road network by road categories.

Adequate periodic maintenance/rehabilitation and potential improving work standards have been defined for each category of the road network, together with preconditions for the implementation and expected effects of their application. Periodic maintenance/rehabilitation and improvement works are predicted as a function of the existing pavement condition and traffic volume. A special attention is paid to the technical and economic analysis of the pavement recycling process (pavement reconstruction) with the Environmental Impact Assessment (EIA). From the standpoint of potential improvement of road network, the relationship between traffic flow (q) and relevant capacity of roads (C) was analyzed using the HDM-4 model in each homogeneous section of the main and regional road network.

The medium-term plan is designed as "mid-term rolling plan" i.e. a framework plan which will be updated annually to reflect completed works and changes to the road network in the previous year. Road sections with modern surfacing (asphalt and concrete surfacing) were analyzed. Unpaved road sections were not analyzed. Also, sections passing through cities were not analyzed.

Programme analysis for the category I and II state road network was carried out using the HDM-4 model (ver. 2.08) by analysing the project life cycle (Life-Cycle Analyses). The programme analysis was made for the period of 15 years (2012-2026) by applying a $10 \%$ discount rate.

In order to rationalize funding, and considering the consequences for the road network, the following cases of budget constraints were analyzed:

- Pessimistic scenario: Constrained budget 10/50/65 million EUR per year,

- Basic (realistic) scenario: Constrained budget 15/85/140 million EUR per year,

- Constrained Budget 75 million EUR per year

- Constrained Budget 100 million EUR per year

- Constrained Budget 120 million EUR per year

- Constrained Budget 150 million EUR per year

- Constrained Budget 200 million EUR per year

Figure 6 shows changes in average pavement surface oughness depending on the funding level.

The work programme proposal was prepared on the basis of the RDB data (condition in 2008/2009), analysis

Table 2. Homogenous links of State roads, categories I and II

\begin{tabular}{|c|c|c|c|c|c|}
\hline \multirow[b]{2}{*}{ Road network } & \multirow{2}{*}{$\begin{array}{c}\text { No. of homogenous } \\
\text { links }\end{array}$} & \multirow{2}{*}{$\begin{array}{l}\text { Length } \\
{[\mathrm{km}]}\end{array}$} & \multicolumn{3}{|c|}{ Average value weighted by homogenous section / link length } \\
\hline & & & $\begin{array}{c}\text { AADT } \\
\text { [veh/dan] }\end{array}$ & $\begin{array}{c}\mid \mathrm{RI} \\
{[\mathrm{m} / \mathrm{km}]}\end{array}$ & $\begin{array}{c}\text { Mean rut dept } \\
{[\mathrm{mm}]}\end{array}$ \\
\hline $\begin{array}{l}\text { Motorways and } \\
\text { semi motorways }\end{array}$ & 73 & $1,062.201$ & 7,284 & 2.14 & 6.59 \\
\hline Main roads & 243 & 4,032.739 & 4,217 & 4.02 & 9.65 \\
\hline Regional roads & 393 & $8,096.404$ & 1,418 & 5.48 & 13.99 \\
\hline Total: & 709 & $13,191.34$ & 2,746 & 4.76 & 12.07 \\
\hline
\end{tabular}




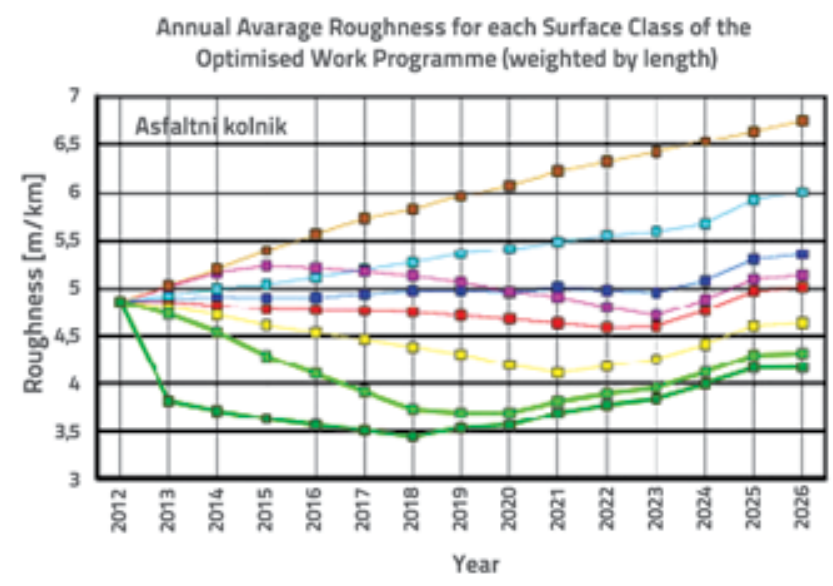

Figure 6. Changes in road network condition for different levels of funding (HDM-4 output) by year, and the economic viability of investments in periodic maintenance/ rehabilitation and improvement works on road network in the Republic of Serbia.

318 homogenous sections/links in the total length of $5,467.8 \mathrm{~km}$ were selected for periodic maintenance/rehabilitation and improvement works in the first five years (2012-2016), according to following investment schedule (Table 3):

Priority sections have been defined according to economic criteria, based on the largest ratio of Net Present Value (NPV) and Investment (KAP). Proposed works include preparatory works, substructure works, asphalt base and of consequences of under-investment in road network maintenance, optimization and distribution of investments surfacing works, works to improve drainage, and traffic signs and equipment. Figure 7 shows the part of the work

HDM - 4

HIGHWAY DEVELOPMENT \& MANAGEMENT $\quad$ Datum 25-09-2019

Program radova optimiziran po godinama Valuta: mil euR

01_Work Programme 2012-2016 upd

\begin{tabular}{|c|c|c|c|c|c|c|c|c|c|}
\hline Codina & Dionica & Klasta puta & $\begin{array}{c}\text { Ooling } \\
0 \mathrm{~m})\end{array}$ & $\begin{array}{l}\text { POCP } \\
\text { vid }\end{array}$ & Opls radosa & MVIXPP & $\begin{array}{c}\text { Fin. } \\
\text { moskion } \\
\end{array}$ & \begin{tabular}{|c|}
$\begin{array}{c}\text { Fn. Trobion } \\
\text { pokn }\end{array}$ \\
\end{tabular} & $\begin{array}{c}\text { Kumulativid } \\
\text { trothew }\end{array}$ \\
\hline & 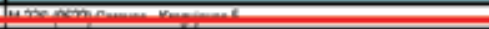 & thines & & 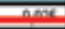 & 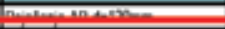 & Intin & in & $\mathrm{xam}$ & 需 \\
\hline & 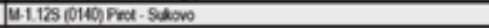 & Magurain & 146 & 4641 & Pcoplane AB d- 20mm & 111.19 & 369 & 0239 & 4916 \\
\hline & Thom & thenente & 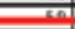 & sine & 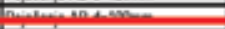 & $\operatorname{men}$ & in & लाm & \\
\hline & 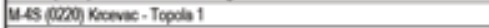 & Ulogierini & 46 & 7653 & Poiplente AB \& $900 \mathrm{~mm}$ & 9790 & 0859 & 0.180 & 7147 \\
\hline & 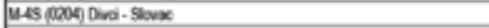 & Mopering & 72 & 7361 & Popiolene AB \& $=000 \mathrm{~mm}$ & 938 & 1450 & $0 \times 0$ & 807 \\
\hline & 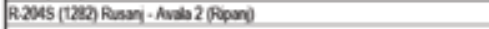 & Regoninin & 199 & 862 & Poptone NBd-1000m & 2146 & 4.198 & 0211 & 12000 \\
\hline & 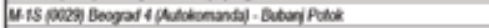 & 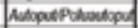 & 2.6 & H, & Shugne 50 izanima d $120 \mathrm{~mm}$ & $2 \times 10$ & 360 & exar & 1000 \\
\hline & 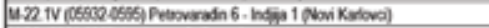 & Wogperaini & 48 & 5606 & Popleni, AB \& $220 \mathrm{~mm}$ & 8451 & 3680 & 0235 & 990 \\
\hline & 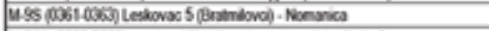 & Wogstosin & 55 & 4749 & Poptone NB d $120 \mathrm{~mm}$ & 8394 & 1270 & 0220 & 21.191 \\
\hline & 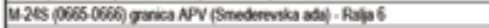 & Woptrain & 100 & 6.300 & Poptrie AB $+100 \mathrm{~mm}$ & 2005 & 2.152 & 0210 & 20312 \\
\hline & 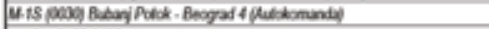 & 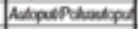 & 26 & 31,00 & Shugen 50 izanima d $120 \mathrm{~mm}$ & 7665 & 360 & 033 & 27010 \\
\hline & 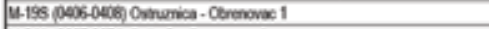 & Mapierain & 173 & $\pi 1.604$ & Poidinie AB d-1000 $\mathrm{rm}$ & 7301 & $4 \mathrm{ag}$ & 0258 & 31647 \\
\hline & 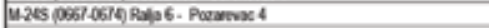 & Wogotian & 233 & $9.3 \times$ & Poplane AB d- $100 \mathrm{~mm}$ & 7230 & 5000 & 0215 & 36649 \\
\hline & 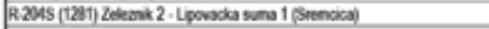 & Peoponahn & 107 & 9238 & Poptone AB d $50 \mathrm{~mm}$ & 7000 & 1500 & 0.100 & 38.152 \\
\hline & 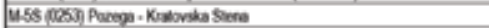 & Wopistini & 79 & 9013 & Poiplane AB d $10 \mathrm{~mm}$ & 6500 & 1520 & 0.196 & 3960 \\
\hline & 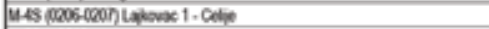 & Hoporain & 44 & 7,436 & 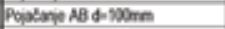 & 6808 & 080 & 0.200 & 45.581 \\
\hline & 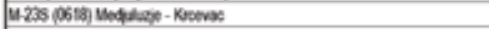 & Ulapotin & 124 & 7,005 & 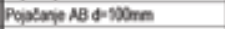 & 6785 & $23 \times 9$ & 0.193 & 2000 \\
\hline & 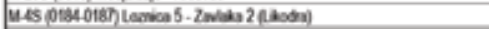 & Ulopinatin & 273 & 4798 & Poplane AB d $120 \mathrm{~mm}$ & 6762 & 53316 & 0.196 & 43276 \\
\hline & 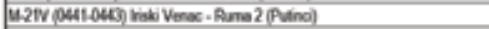 & 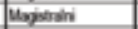 & 183 & $10 \times 2$ & Poiplonie AB d-Nomm & 6008 & 3406 & 0.190 & $51 \mathrm{~m}$ \\
\hline & 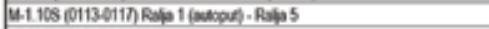 & Uopoterain & 40 & 6.580 & Poplane AB d- 500mm & 6500 & 0871 & 02200 & 5250 \\
\hline & 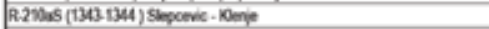 & Pregoninin: & 95 & 2500 & Shyene Soizanimu of $120 \mathrm{~mm}$ & 6300 & 0894 & 0096 & 5306 \\
\hline & 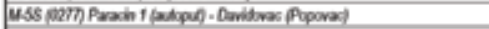 & Ulopistidi & 33 & sens & 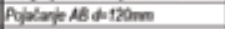 & 5960 & 0.061 & $0 \times 0$ & 5438 \\
\hline & 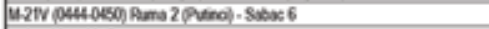 & Wopotrin & 307 & 10.465 & Poptinie AB \& $\$ 50 \mathrm{~mm}$ & $57 m$ & 5834 & 0.160 & 60182 \\
\hline & 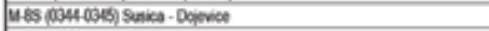 & Magotrain & 302 & 3.68 & Poplatio AB \&-20mm & 5771 & $628 \pi$ & 0200 & 66.40 \\
\hline & 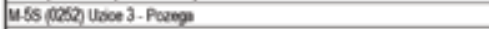 & Uopgering & 217 & 11,02 & Pooplane AB d-SOMm & 5.158 & 3.000 & 0.157 & $69+9$ \\
\hline & 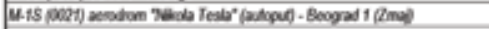 & 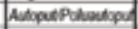 & 6.8 & 26,300 & uil 50 and Replace $120 \mathrm{~mm}$ & 5005 & 2600 & 0350 & $n 49$ \\
\hline & U. 185 (0111013) Detace - Mas & Mopstain & Q1. & 400 & Poptane AB d-120mm & 4800 & 3000 & 02001 & 76.117 \\
\hline & 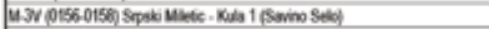 & Wopgersin & 331 & 403 & 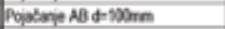 & 4600 & 6751 & 0200 & 8200 \\
\hline & 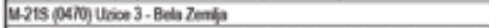 & Mogienini & 85 & 10008 & Poiplarie AB d-Nmm & 478 & 1858 & 0219 & 3475 \\
\hline & 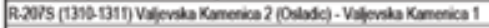 & Reoponihin & 45 & 2 GAS & Paiplane AB d-120m & $4 \pi 4$ & 0834 & 0.87 & 8550 \\
\hline & 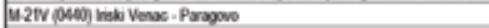 & Wogstain & 37 & 52215 & Poiptone $A B d=7 \mathrm{~mm}$ & 4416 & 0650 & $0.1 \mathrm{~m}$ & 85200 \\
\hline & 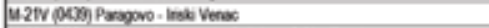 & Woptrain & 44 & 5245 & Poptone AB dort28m & 4300 & 1051 & 02011 & 8727 \\
\hline & 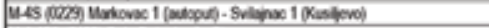 & Mogation & 65 & 4004 & Popline $A B d-120 \mathrm{~mm}$ & 4278 & 1301 & 02001 & $\sin$ \\
\hline & 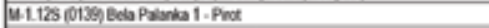 & Wogstain & 273 & 4565 & Pogatone $\mathrm{NBd}=\mathrm{Nmm}$ & 4117 & 5004 & 0.100 & 9065 \\
\hline & 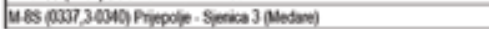 & Wupgerain & 177 & 2812 & Paremed noconshusion & 410 & 5.175 & 0280 & 9801 \\
\hline
\end{tabular}

Figure 7. Part of work programme report for 2012

Table 3. Work programme investment costs for periodic maintenance/rehabilitation of road network

\begin{tabular}{|c|c|c|c|c|c|c|}
\hline Item & 2012. & $\mathbf{2 0 1 3 .}$ & $\mathbf{2 0 1 4 .}$ & $\mathbf{2 0 1 5 .}$ & $\mathbf{2 0 1 6 .}$ & Total \\
\hline $\begin{array}{c}\text { Investment Value } \\
\text { [mil. } € \text { ] }\end{array}$ & 199.7 & 199.6 & 199.9 & 199.9 & 199.6 & 998.6 \\
\hline $\begin{array}{c}\text { Length of road } \\
\text { networ [km] }\end{array}$ & 958.2 & $1,078.5$ & $1,148.4$ & $1,108.6$ & $1,174.1$ & $5,467.8$ \\
\hline
\end{tabular}


programme report for 2012, based on the results of the HDM-4 programme analysis.

In accordance with the proposed work programme, PE "Roads of Serbia" has selected 30 priority sections for further elaboration at the expert (high-level) project level analysis in order to confirm the technical and economic feasibility of the proposed works, and to provide financial resources for the realization of the works (in this case joint financing by the World Bank, EIB, and EBRD). After completion of the expert project level analysis and confirmation of the technical and economic feasibility of the project, the work continues with the preparation of the Final/Detailed Design for periodic maintenance/rehabilitation and improvement works, and with the preparation of tender documents for the works.

\section{Expert (high-level) project analyses for selected sections}

\subsection{Methodology}

The technical and economic analysis of the feasibility of periodic maintenance/rehabilitation and improvement works for selected priority sections of category I and II state roads of the Republic of Serbia was conducted using the HDM-4 model (Highway Design and Management Model, ver. 2.08). The project analysis by section was used in this case. The project level analysis was based on the data from Road Data Base (RDB), on expert judgments following joint visit of sections by maintenance engineers, supervising engineers, and engineers from PE "Roads of Serbia", and also on the review of digital video recordings in the bureau (Figure 8).

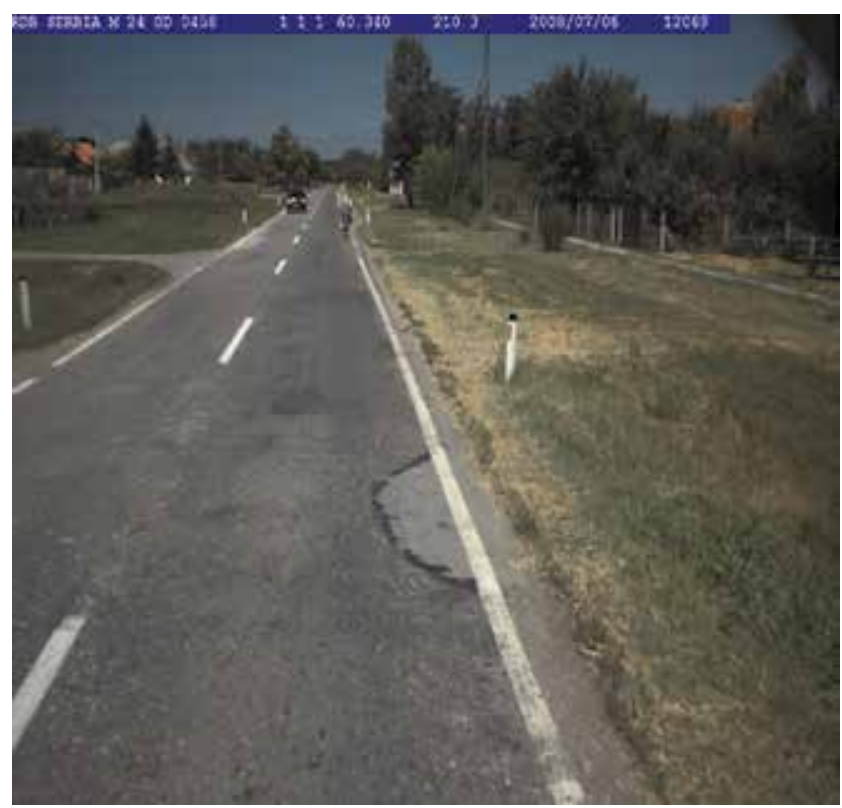

Figure 8. Digital video record of section (ARAN, 2008)
The Information Quality Level is IQL-2 which is appropriate for the conduct of project analyses. In case of insufficient or inadequate data, certain assumptions were accepted and/or "default" values from the HDM-4 model were used.

During general analysis, priority sections were divided into homogeneous sub-sections (where necessary) according to:

- Traffic load,

- Pavement type and structure,

- Dominant road geometry on the homogenous section/link,

- Measured pavement roughness and pavement distress level.

During assessment of the pavement structure condition and its bearing capacity, the procedure for determining the structural number was used in accordance with AASHTO (the American Association of State Highway and Transportation Officials) recommendations, and according to the prevailing national standard SRPS U.C4.012, based on the size of the equivalent traffic load, type and condition of materials in pavement layers, and bearing capacity of material in the pavement subgrade.

Pavement rehabilitation measures were determined at the expert level on the basis of the type and degree of pavement surface distress and the data contained in the Road Data Base (RDB), as a function of the expected traffic load in the project period and recommended works from programme analysis.

The difference in costs and benefits between the base alternative "minimum work for road maintenance" and analyzed alternatives of "periodic maintenance/rehabilitation and improvement works", was calculated for each year in the period of $1+10=11$ years. In addition, the Net Present Value (NPV) and Internal Rate of Return (IRR) were calculated for each individual project.

The sensitivity analysis of results was conducted through simulation of traffic decrease ( $\mathrm{dT}=-20 \%$ ) and work cost increase $(\mathrm{dC}=+20 \%)$ in order to illustrate the importance of changes concerning investment costs, as well as the changes concerning predicted traffic flows. The economic analysis is based on the following assumptions:

- Analysis of traffic flows on considered sections/links, and traffic growth prognosis in the design period, are based on the traffic volume data for 2010,

- Period of the analysis is $1+10=11$ years,

- The first year of the analysis is 2012 while the first year of exploitation is 2013

- The last year of the analysis is 2022

- Work costs are defined on the basis of the official P.E. "Roads of Serbia" price list,

- Discount rate is $10 \%$,

- Economic / financial costs ratio is 0.74,

- Costs of traffic accidents were not analyzed.

The expert project level analysis includes a systematic overview of the following information and analysis results for each of the selected priority homogeneous section/link of the road network (Table 4 ). 
Table 4. Overview of the information and results of expert project level analysis

1. LOCATION (basic data about section/link according to reference location system)

2. OVERVIEW MAP (mapsgoogle.com)

3. TRAFFIC LOAD (volume and structure of traffic load)

4. GEOMETRIC CHARACTERISTICS

4.1 Cross-section (elements of cross section)

4.2 Horizontal plan - layout (elements of layout plan)

4.3 Longitudinal profile (elements of longitudinal profile)

5. PAVEMENT STRUCTURE (type and structure of pavement)

6. PAVEMENT CONDITION (indicators of pavement condition)

7. STRUCTURES (basic data about structures on the section/link)

8. TRAFFIC SIGNS AND ROAD FACILITIES

9. DESCRIPTION OF ANALYZED WORKS
9.1 Base Alternative (minimum maintenance works)

9.2 Periodic maintenance/Rehabilitation and Improvement works

10. INVESTMENT VALUE OF WORKS

11. ECONOMIC ANALYSES

11.1 Change in pavement condition during the period of analysis

11.2 Economic indicators summary

11.3 Sensitivity analyses

12. FUEL CONSUMPTION AND ENVIRONMENTAL EFFECTS

12.1 Fuel consumption

$12.2 \mathrm{CO}_{2}$ emission
The results of susceptibility analysis show that the stability of the main solution is acceptable, especially in the light of the fact that benefits due to the decrease in the number of traffic accidents, and other exogenous benefits concerning ecology and social aspects, were not considered in this analysis. An example of the expert project level analysis for the category I state road section M 1:12, Pirot - Sukovo, $14,627 \mathrm{~km}$ in total length, is shown in Table 5.

Table 5. Example of the expert (high-level) project analyses for road maintenance - improvement works

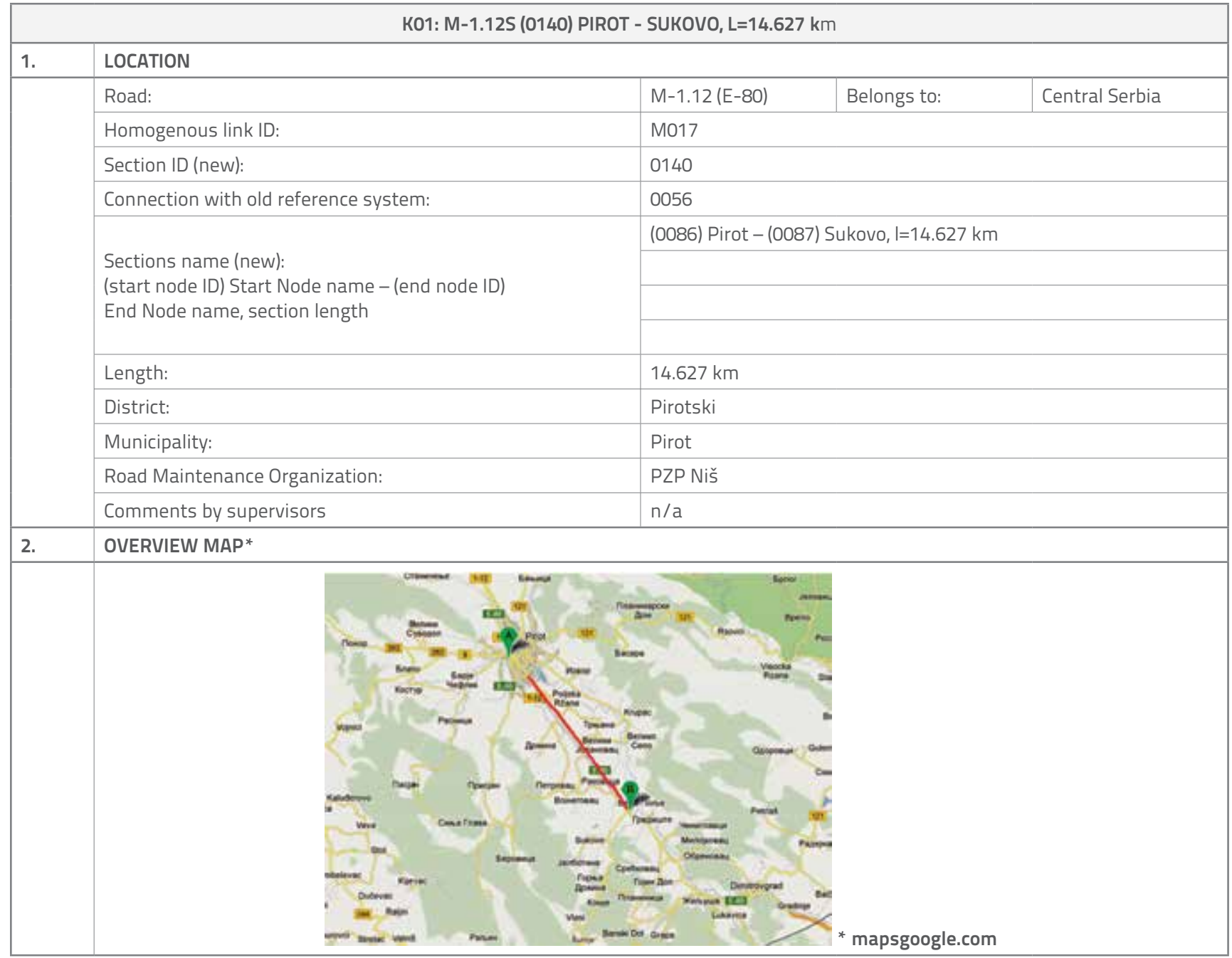


Table 5. Example of the expert (high-level) project analyses for road maintenance - improvement works (continued)

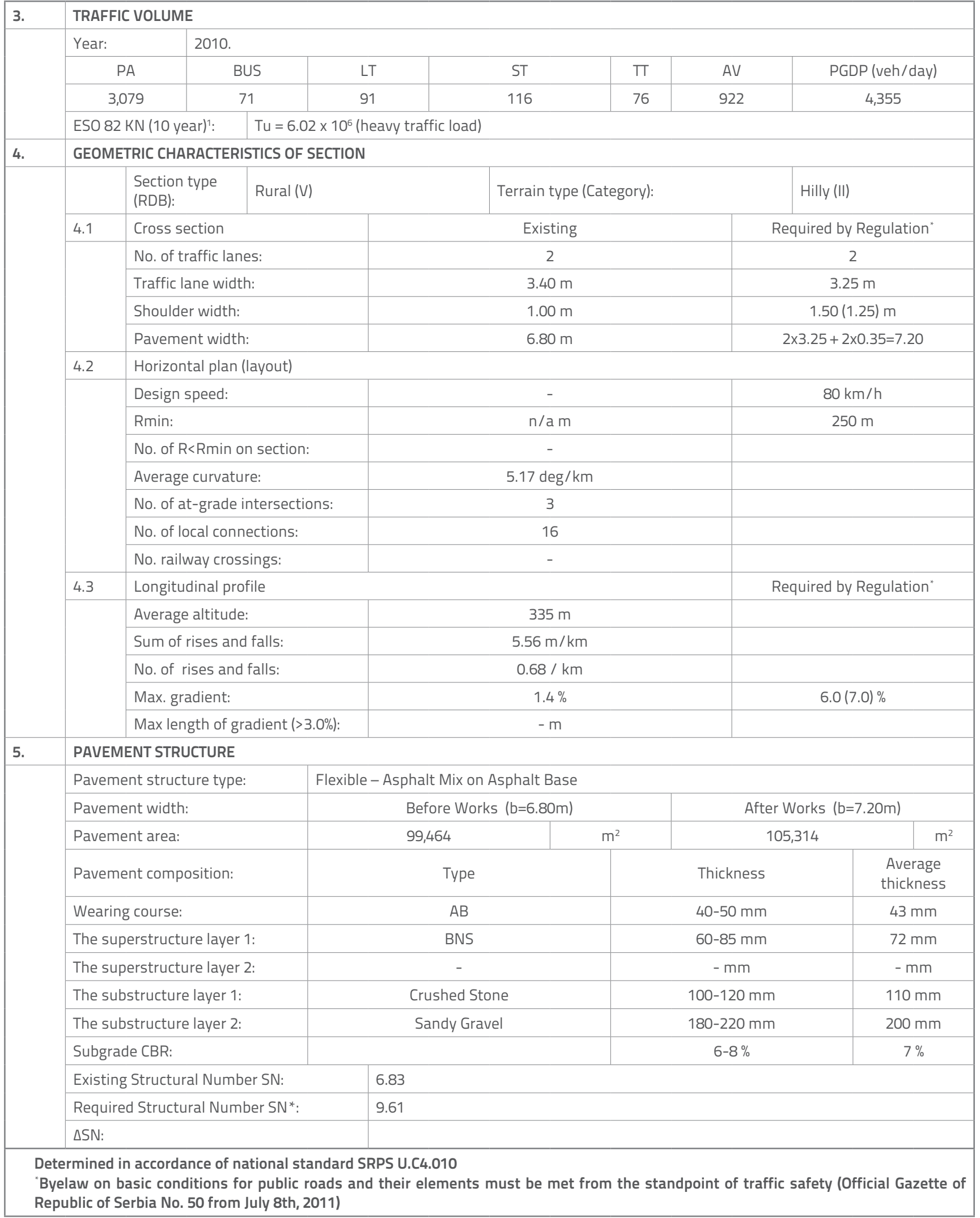


Table 5. Example of the expert (high-level) project analyses for road maintenance - improvement works (continued)

\begin{tabular}{|c|c|c|c|c|c|c|c|}
\hline 6. & PAVE & JT CONDITION & & & & & \\
\hline & Year & & & 2008. & & 2010. & \\
\hline & Roug & SS (IRI): & & $6.05 n$ & & $6.96 \mathrm{~m} / \mathrm{kr}$ & \\
\hline & Mear & depth: & & 7.49 & & $10.49 \mathrm{~mm}$ & \\
\hline & Total & king Area: & & 1.7 & & $4.47 \%$ & \\
\hline & Defle & (D300): & & $171-25$ & & $-\mu m$ & \\
\hline & Textu & epth: & & 0.66 & & $-m m$ & \\
\hline 7. & STRU & RES & & & & & \\
\hline & Total & of culverts: & & & & & \\
\hline & & of bridges: & & & & & \\
\hline & Total & th of bridges: & & & & & \\
\hline & Total & of overpasses & & & & & \\
\hline & Total & th of overpas & & & & & \\
\hline & Total & of tunnels/ga & ries: & & & & \\
\hline & Total & th of tunnels & alleries: & & & & \\
\hline & Total & th of retainin & valls: & & & & \\
\hline & Aver & eight of retai & gg walls: & & & & \\
\hline 8. & TRAF & IGNS AND RO & D FACILITIE & & & & \\
\hline & Total & of traffic sign & & & & & \\
\hline & Total & th of guardra & & & & & \\
\hline & Total & th of protecti & net: & & & & \\
\hline 9. & DESC & ION OF ANAL & ED WORKS & & & & \\
\hline & Prog & ne analyses: & 2012: AC & $\mathrm{mm}$ & & & \\
\hline & 9.1 & Base Altern & ve (minims & ce work & & & \\
\hline & 9.2 & Periodic ma & enance/R & nd Impr & ent works & & \\
\hline 10. & INVE & ENT VALUE O & NORKS & & & & \\
\hline & R.b. & Work Positic & & & $\begin{array}{c}\text { Economic Cost } \\
{[€]}\end{array}$ & $\begin{array}{c}\text { Financial Cost } \\
{[€]}\end{array}$ & [\%] \\
\hline & 1. & Preparatory & orks & & $70,529.6$ & $95,127.0$ & 2.1 \\
\hline & 2. & Substructur & Norks - wic & & $66,482.6$ & $89,809.8$ & 2.0 \\
\hline & 3. & Superstruct & e works & & $2,214,761.8$ & $2,949,329.8$ & 64.5 \\
\hline & 4. & Structure $\mathrm{w}$ & & & $654,633.6$ & $884,640.0$ & 19.3 \\
\hline & 5. & Drainage wc & & & $127,723.0$ & $172,598.6$ & 3.8 \\
\hline & 6. & Regulation & roadside & & $136,900.0$ & $185,000.0$ & 4.0 \\
\hline & 7. & Traffic signa & ation and & & $146,664.9$ & $198,195.9$ & 4.3 \\
\hline & & & & (1-7): & $3,417,695$. & $4,574,701.0$ & 100.0 \\
\hline & & & & (10\%) & $341,769.6$ & $457,470.1$ & \\
\hline & & & Tot & Value: & $3,759,465.2$ & $5,032,171.1$ & \\
\hline & & & Total Inv & / km: & $257,022.3$ & $344,033.0$ & \\
\hline
\end{tabular}


Table 5. Example of the expert (high-level) project analyses for road maintenance - improvement works (continued)

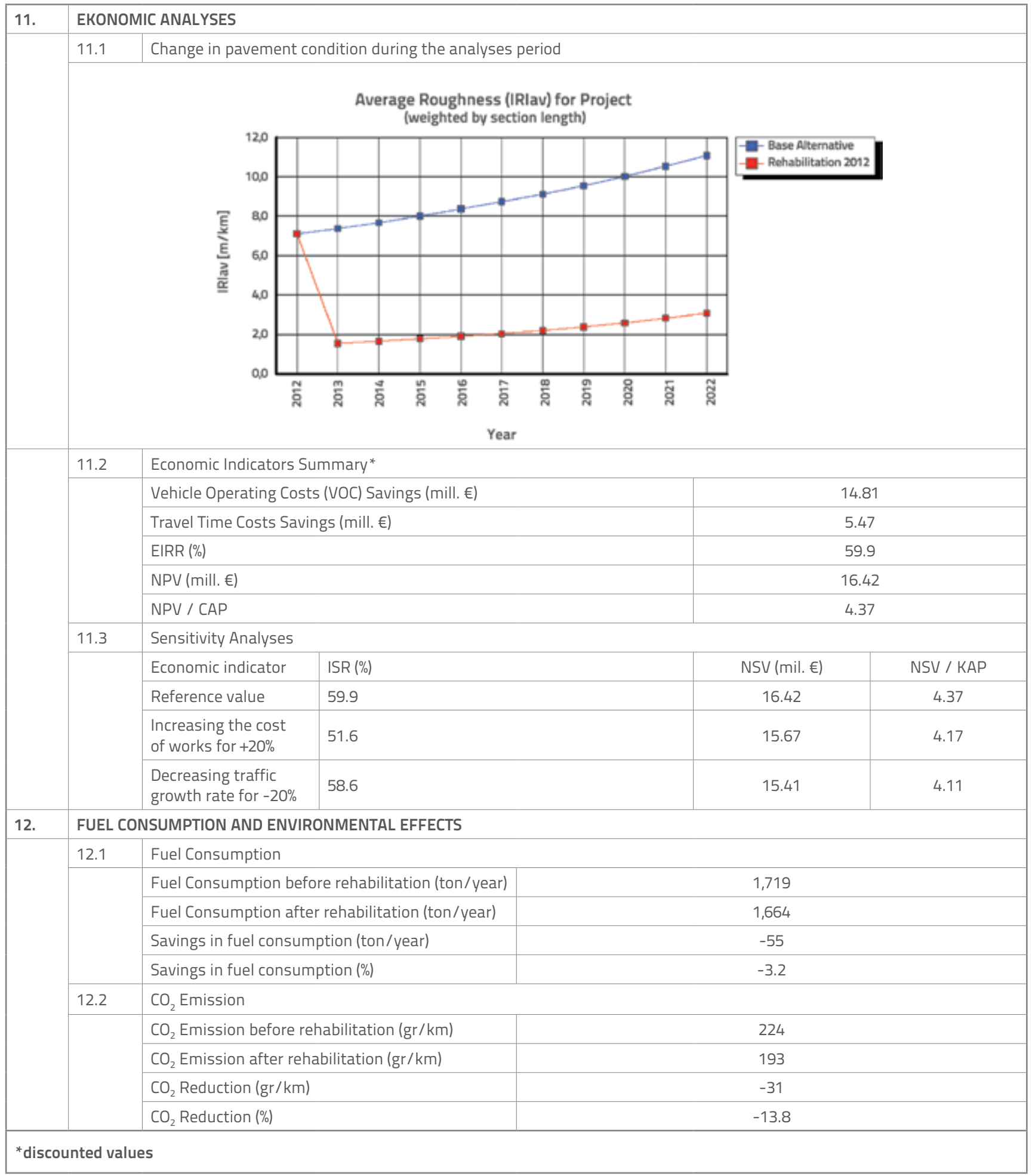




\section{Conclusion}

Based on the programme analysis for category I and II state road network of the Republic of Serbia measuring 13,191.34 $\mathrm{km}$ in total length, 30 priority sections of $476.3 \mathrm{~km}$ in total length were selected for financing of periodic maintenance/ rehabilitation and improvement works by the International Financial Institutions (World Bank, EIB, EBRD) during the period 2012-2016, as well as 19 sections with the total length of $326.7 \mathrm{~km}$ for financing by the NAMA (Nationally Appropriate Mitigation Action) programme. Expert (high-level) project level analyses were made for the selected priority sections based on engineering diagnostics using the Road Data Base (RDB) and the HDM-4 model for the development and management of roads. Appropriate periodic maintenance/ rehabilitation and improvement works and environmental impacts were evaluated in the scope of the project level analyses. In addition to the periodic maintenance - pavement rehabilitation works, the analysis included an estimation of future works related to the widening, drainage improvement, traffic signalization and road facilities improvement, and roadside regulation (intersections, access roads, and local connections). The procedure was successfully conducted and approved by the World Bank from Washington and by the NAMA programme in the scope of application for funding maintenance and improvement of the road network in Serbia. On the basis of the programme analysis and expert (highlevel) project level analysis for selected priority sections/links, funds were approved and allocated for periodic maintenance / rehabilitation and improvement works by the World Bank, EIB and EBRD in the period 2013-2017.

\section{Acknowledgements}

The research presented in this paper was conducted with the support of the PE "Roads of Serbia" using the data from the Road Data Base (RDB). The paper also presents a part of the research supported by the Ministry of Science and Technological Development of the Republic of Serbia within the project TR 36017 entitled: "Utilization of by-products and recycled waste materials in concrete composites in the scope of sustainable construction development in Serbia: investigation and environmental assessment of possible applications". The authors extend their thanks to all authorities that approved the use of the data for their kind assistance and understanding.

\section{REFERENCES}

[1] PIARC Terminology-Dictionary-Road-Transport, http://www. piarc.org, 05.02.2013.

[2] Principles of Pavement Preservation, http://www.fhwa.dot. gov, 05.02.2013.

[3] Botswana Road Maintenance Manual (BRMM), Part A, Overview and Maintenance Management, Ministry of Transport and Communication, Gaborone, 2010.

[4] Robinson, R., Danielson, U., Snaith, M.: Road Maintenance Management, Concepts and Systems, First edition, Macmillan Press Ltd., London, 1998.

[5] Paterson, W.D.O., Scullion, T.: Information Systems for Road Management: Draft Guidelines on System Design and Data Issues. World Bank Technical Paper INU 77, Infrastructure and Urban Development Department, The World Bank, Washington, D.C., 1990.

[6] Javno preduzeće "Putevi Srbije", http://www.putevi-srbije.rs, 05.02.2013.

[7] Zakon o javnim putevima, Službeni glasnik RS br. 101/2005 i 123/2007.

[8] Radović, N.: Izrada programske analize za državnu putnu mrežu i indikatora uspešnosti realizacije Projekta Rehabilitacije Saobraćaja, Završni izveštaj, JP "Putevi Srbije", Beograd, 2011.

[9] JV CPV-NIEVELT, Baza podataka o putevima, Završni izveštaj, JP "Putevi Srbije", Beograd, 2010.

[10] Sršen, M., Kršić, I., Domandžić, D.: Use of HDM-4 model for county road management, GRADEVINAR 54 (2002) 1, 23-30. 